\title{
Prozone effects in microscopic agglutination tests for leptospirosis in the sera of mice infected with the pathogenic Leptospira interrogans serovar Canicola
}

\author{
Fabio Hiroto Shimabukuro ${ }^{1 /+}$, Veruska Maia da Costa ${ }^{2}$, Rodrigo Costa da Silva ${ }^{2}$, Hélio Langoni ${ }^{2}$, \\ Aristeu Vieira da Silva ${ }^{3}$, Lídia Raquel de Carvalho ${ }^{4}$, Paulo Francisco Domingues ${ }^{2}$ \\ ${ }^{1}$ Centro de Laboratório Regional XI, Instituto Adolfo Lutz, Sorocaba, SP, Brasil ${ }^{2}$ Núcleo de Pesquisas em Zoonoses, \\ Departamento de Higiene Veterinária e Saúde Pública, Faculdade de Medicina Veterinária e Zootecnia, \\ ${ }^{4}$ Departamento de Bioestatística, Instituto de Biociências, Universidade Estadual Paulista, Botucatu, SP, Brasil \\ ${ }^{3}$ Departamento de Ciências Biológicas, Universidade Estadual de Feira de Santana, Feira de Santana, BA, Brasil
}

Mice experimentally infected with a pathogenic strain of Leptospira interrogans serovar Canicola produced false negative results (prozone effect) in a microscopic agglutination test (MAT). This prozone effect occurred in several serum samples collected at different post-infection times, but it was more prominent in samples collected from seven-42 days post-infection and for 1:50 and 1:100 sample dilutions. This phenomenon was correlated with increased antibody titres in the early post-infection phase. While prozone effects are often observed in serological agglutination assays for the diagnosis of animal brucellosis and human syphilis, they are not widely reported in leptospirosis MATs.

Key words: microscopic agglutination test - prozone effect - leptospirosis

Leptospirosis is a globally distributed infectious disease caused by spirochetes of the genus Leptospira. It affects humans and a wide variety of domestic and wild animals. This zoonotic disease is endemic in underdeveloped and developing countries and is considered emerging or re-emerging in developed countries (Bharti et al. 2003). Leptospirosis is mainly diagnosed in animals and humans through serological tests (O'Keefe 2002).

The microscopic agglutination test (MAT) is a standard serological assay that detects antibodies against Leptospira spp in serum samples, where direct agglutination of serum antibodies with live bacteria is observed via dark-field microscopy. The starting serum dilution for screening using this test is 1:100 and when positive, samples are retested in two-fold serial dilutions to determine the antibody titre (WHO 2003).

The agglutination test has been widely applied for diagnosis because it is simple and easy to perform. However, excess antibodies in a serum sample can inhibit the antigen-antibody interaction and subsequent agglutination reaction, leading to a false negative result, which is known as a prozone phenomenon or effect (Tizard 2004). Prozone effects have often been reported in diagnostic tests for animal and human brucellosis

\footnotetext{
doi: 10.1590/0074-0276108052013022

Financial support: FAPESP (2006/02769-6)

+ Corresponding author: fhsvet@bol.com.br

Received 23 August 2012

Accepted 13 May 2013
}

(Plackett \& Alton 1975, Guven et al. 2006, Buzgan et al. 2007) and human syphilis (Azevedo et al. 2006), mainly in patients co-infected with human immunodeficiency virus (Lynn \& Lightman 2004, Smith \& Holman 2004). Apart from the findings of some studies performed in sheep, goats and horses (Malkin 1984, Knudtson \& Fetters 1990), it is unknown whether this effect occurs in MATs for leptospirosis.

In mice experimentally infected with a pathogenic strain of Leptospira interrogans serovar Canicola, we previously observed false negative reactions (a prozone effect) in MATs of serum samples collected at different times post-infection. In the present study, we evaluated this phenomenon.

We inoculated 60 inbred, albino female Swiss/Uni mice at four-six weeks of age, weighing 30-40 g. The mice were free of pathogens and were acquired from the Multidisciplinary Centre for Biological Research of the State University of Campinas, Campinas, state of São Paulo (SP), Brazil. The animals were allocated to three groups of 20 mice each, 14 of which were inoculated with the pathogenic bacteria, while six were inoculated with sterile Ellinghausen-McCullough-Johnson-Harris $(\mathrm{EMJH})$ liquid medium as a negative control. The strain used in this study, from L. interrogans serovar Canicola, was isolated from a porcine liver in Londrina, state of Paraná, Brazil and is pathogenic in hamsters (Freitas et al. 2004). The animals were kept in $41 \times 34$ $\mathrm{x} 16 \mathrm{~cm}$ (length $\mathrm{x}$ width $\mathrm{x}$ height) polypropylene cages with stainless steel perforated floors covered with autoclaved shavings and were supplied with commercial food and drinking water ad libitum. The study protocol was approved by the Ethical Committee on Animal Use (CEEA) of the Faculty of Veterinary Medicine and Animal Science of São Paulo State University, Botuca- 
tu, SP, Brazil (64/2006-CEEA). L. interrogans serovar Canicola was maintained in the laboratory through alternating passages in hamsters and semi-solid Fletcher medium. To prepare the inoculum, bacteria were cultured in EMJH liquid medium for seven days. Leptospires were counted in a Petroff-Hauser chamber with a dark-field microscope and the final concentration was adjusted to $2.5 \times 10^{5}$ microorganisms $/ \mathrm{mL}$. The volume of this inoculum administered intraperitoneally to each animal was $0.5 \mathrm{~mL}$.

For serological monitoring, blood samples were initially collected at short, daily intervals until the second week, then weekly until day 77 and, finally, every 14 days until the end of the experiment (on days 4, 7, 14, $21,28,35,42,49,56,63,70,77,91,105,119,133,147$, 161 and 175). During each sampling event, five inoculated animals $(n=5)$ and two negative controls were randomly chosen and re-sampling of the chosen animals did not occur until the 35th day post-inoculation. After this date, the animals were again subjected to sampling. This methodology was adopted because at days 7, 14, 21, 28, 35, 91 and 175 post-inoculation, five inoculated animals and two negative controls were sacrificed for tissue collection. For blood collection, the retro-orbital venous plexus was punctured and $0.5 \mathrm{~mL}$ of blood was collected in $1.5 \mathrm{~mL}$ plastic microtubes via capillary tubes. The blood samples were drained after clot retraction and centrifuged for $10 \mathrm{~min}$ at 2,500 rpm. The sera were then stored in new $1.5 \mathrm{~mL}$ plastic microtubes at $-20^{\circ} \mathrm{C}$ until serological testing.

The MAT was performed according to the methodology described by the World Health Organization (WHO 2003) using 24 Leptospira spp serovars (Australis, Bratislava, Autumnalis, Butembo, Castellonis, Bataviae, Canicola, Whitcombi, Cynopteri, Djasiman, Sentot, Grippotyphosa, Hebdomadis, Copenhageni, Icterohaemorrhagiae, Javanica, Panama, Pomona, Pyrogenes, Hardjo, Wolffi, Shermani, Tarassovi and Patoc). Live cultures were grown for seven days in EMJH liquid medium and diluted 1:3 in $0.01 \mathrm{M}$ phosphate buffered saline, $\mathrm{pH} 7.2$, which corresponded to a concentration of approximately $2.0 \times 10^{8}$ leptospires $/ \mathrm{mL}$. Each serum sample was initially diluted 1:50 and tested for all serovars; samples showing $50 \%$ or more agglutination than the negative control were considered positive. The positive samples were tested again in two-fold serial dilutions for the serovar(s) that reacted previously. The endpoint titre corresponded to the reciprocal of the highest serum dilution that showed $50 \%$ agglutination, as measured by comparison with the negative controls. The obtained data were tabulated in an Excel spreadsheet. For statistical analysis, the data were compared using a chi-square test at a significance level of $\alpha=0.05$ (Triola 2005).

The animals inoculated with the pathogenic strain of $L$. interrogans serovar Canicola seroconverted, but showed no susceptibility to the disease symptoms. Serological screening produced no reactions to any Leptospira spp serovars other than that used for inoculation, indicating a specific immune response against the Canicola serovar.
False negative reactions were observed in several serum samples at dilutions of 1:50, 1:100 and 1:200. Ten of the 95 serum samples were discarded due to inconsistent results. Of the 85 remaining samples, two tested negative in the initial 1:50 dilution. Among the 83 reactive samples, false negative reactions occurred in 47 (56.6\%) of the 1:50 dilutions, $26(31.3 \%)$ of the $1: 100$ dilutions and one (1.2\%) of the 1:200 dilutions.

Based on the distribution of false negative results for the 1:50 and 1:100 dilutions and the final titres obtained from each serum sample, we found that the prozone effect increased when the titre of antibodies was high. This trend was statistically significant $(\mathrm{p}<0.05)$ (Tables I, II).

The false negative results were also compared between samples collected at different times (Tables III, IV). There was a significant difference $(p<0.05)$ between the number of false negative results obtained during the initial post-infection period, especially between seven- 42 days post-infection and the negative results obtained later in the infection.

Such false negative results correspond to an excessive increase in the concentration of antibodies against a specific antigen. An antibody concentration much higher than the antigen density may inhibit agglutination (Plackett \& Alton 1975, Azevedo et al. 2006, Guven et al. 2006, Buzgan et al. 2007).

The complement system may also interfere with agglutination, as shown by Malkin (1984). To reduce this phenomenon, complement can be inactivated by heat-treating serum in a $56^{\circ} \mathrm{C}$ water bath or by adding ethylenediamine tetraacetic acid. Serum inactivation is performed in MATs to diagnose human leptospirosis (WHO 2003), but it is rarely applied when testing animal samples. To eliminate excess antibodies and decrease the prozone effect, serum samples can be diluted further.

The cut-off value that is commonly used for sample dilutions assayed by MATs is 1:100, which is the standard value for screening (WHO 2003). Because live antigens are used, antigen standardisation, which depends on the growth time and leptospire density of cultures, is difficult (O'Keefe 2002). Considering that false negative results were produced by several samples in our study, we must emphasise the importance of reducing the prozone effect in serum samples tested via MATs.

In both diagnostic and research protocols, serum inactivation (Knudtson \& Fetters 1990), higher serum dilutions and higher antigen concentrations can help minimise the prozone effect. However, these procedures should be carefully evaluated because they directly influence the results and standardisation of MATs. Although the antigens were prepared consistently for all of the MATs performed in this study, unknown factors led to differences in their density. These differences in the ratios of antigens to antibodies may have produced prozone effects. Although prozone effects are rarely reported in MATs, they should be further studied so that the results obtained during screening and titration are correct and reliable, especially in animal serum samples that are not inactivated prior to testing. 


\section{TABLE I}

False negative results for 1:50 dilution in microscopic agglutination test of sera from mice experimentally infected with Leptospira interrogans serovar Canicola, according to the final titres obtained in each sample

\begin{tabular}{lccc}
\hline & \multicolumn{2}{c}{$\begin{array}{c}\text { False negative result } \\
\text { for 1:50 dilution }\end{array}$} & \\
\cline { 2 - 3 } & $\begin{array}{c}\text { Yes } \\
\mathrm{n}(\%)\end{array}$ & $\begin{array}{c}\text { No } \\
\mathrm{n}(\%)\end{array}$ & $\begin{array}{c}\text { Total } \\
\text { n }(\%)\end{array}$ \\
\hline Titre $^{a}$ & $17(37.8)$ & $28(62.2)$ & $45(100)$ \\
$\leq 800$ & $30(78.9)$ & $8(21.1)$ & $38(100)$ \\
$\geq 1.600$ & 47 & 36 & $83(100)$ \\
\hline Total & & &
\end{tabular}

$a$ : chi-square test $(\mathrm{p}<0.05)$.

\section{TABLE II}

False negative results for 1:100 dilution in microscopic agglutination test of sera from mice experimentally infected with Leptospira interrogans serovar Canicola, according to the final titres obtained in each sample

\begin{tabular}{|c|c|c|c|}
\hline \multirow[b]{2}{*}{ Titre $^{a}$} & \multicolumn{2}{|c|}{$\begin{array}{l}\text { False negative result } \\
\text { for } 1: 100 \text { dilution }\end{array}$} & \multirow[b]{2}{*}{$\begin{array}{l}\text { Total } \\
\mathrm{n}(\%)\end{array}$} \\
\hline & $\begin{array}{l}\text { Yes } \\
\mathrm{n}(\%)\end{array}$ & $\begin{array}{c}\text { No } \\
\mathrm{n}(\%)\end{array}$ & \\
\hline$\leq 800$ & 8 (17.8) & 37 (82.2) & $45(100)$ \\
\hline$\geq 1.600$ & $18(47.4)$ & $20(52.6)$ & $38(100)$ \\
\hline Total & 26 & 57 & $83(100)$ \\
\hline
\end{tabular}

$a$ : chi-square test $(\mathrm{p}<0.05)$.

\section{ACKNOWLEDGEMENTS}

To Prof Silvio Arruda Vasconcellos, for having supplied the pathogenic strain of L. interrogans serovar Canicola.

\section{REFERENCES}

Azevedo LKA, Fernandes PSG, Cavalcanti e Silva DGK, Batista Neto MJ, Queiroz MGL, Dantas VCR, Sales VSF, Cavalcanti Jr GB 2006. Caracterização e correlação do fenômeno pró-zona com títulos de soro-reatividade do VDRL e reação de imunofluorescência indireta em soros de pacientes com sífilis. Rev Bras Anal Clin 38: 183-187.

Bharti AR, Nally JE, Ricaldi JN, Matthias MA, Diaz MM, Lovett MA, Levett PN, Gilman RH, Willig MR, Gotuzzo E, Vinetz JM 2003. Leptospirosis: a zoonotic disease of global importance. Lancet Infect Dis 3: 757-771.

Buzgan T, Karsen H, Karahocagil MK, Akdeniz H, Sunnetcioglu M 2007. A case of brucellosis presenting as high titer negative result by standard tube agglutination test. Mikrobiyol Bul 41: 151-154.

Freitas JC, Silva FG, Oliveira RC, Delbem ACB, Muller EE, Alves LA, Teles PS 2004. Isolation of Leptospira spp from dogs, bovine and swine naturally infected. Cienc Rural 34: 853-856.

Guven GS, Cakir B, Oz G, Tanriover MD, Turkmen E, Sozen T 2006. Could remembering the prozone phenomenon shorten our diagnostic journey in brucellosis? A case of Brucella spondylodiscitis. Rheumatol Int 26: 933-935.
TABLE III

False negative results for 1:50 dilution in microscopic agglutination test of sera from mice experimentally infected with Leptospira interrogans serovar Canicola, according to the sampling period

\begin{tabular}{lccc}
\hline & \multicolumn{2}{c}{$\begin{array}{c}\text { False negative result } \\
\text { for 1:50 dilution }\end{array}$} & \\
\cline { 2 - 3 } & Yes & No & Total \\
& $\mathrm{n}(\%)$ & $\mathrm{n}(\%)$ & $\mathrm{n}(\%)$ \\
\hline$\leq 42$ & $22(75.9)$ & $7(24.1)$ & $29(100)$ \\
$>42$ & $25(46.3)$ & $29(53.7)$ & $54(100)$ \\
\hline Total & 47 & 36 & $83(100)$ \\
\hline
\end{tabular}

$a$ : chi-square test $(\mathrm{p}<0.05)$.

\section{TABLE IV}

False negative results for 1:100 dilution in microscopic agglutination test of sera from mice experimentally infected with Leptospira interrogans serovar Canicola, according to the sampling period

\begin{tabular}{lccc}
\hline & \multicolumn{2}{c}{$\begin{array}{c}\text { False negative result } \\
\text { for 1:100 dilution }\end{array}$} & \\
\cline { 2 - 3 } & $\begin{array}{c}\text { Yes } \\
\mathrm{n}(\%)\end{array}$ & $\begin{array}{c}\text { No } \\
\mathrm{n}(\%)\end{array}$ & $\begin{array}{c}\text { Total } \\
\mathrm{n}(\%)\end{array}$ \\
\hline$\leq 42$ & $16(55.2)$ & $13(44.8)$ & $29(100)$ \\
$>42$ & $10(18.5)$ & $44(81.5)$ & $54(100)$ \\
\hline Total & 26 & 57 & $83(100)$ \\
\hline
\end{tabular}

$a$ : chi-square test $(\mathrm{p}<0.05)$.

Knudtson WU, Fetters M 1990. The effect of heat-inactivation on agglutinating antibody titers to Leptospira interrogans. J Vet Diagn Invest 2: 149-150.

Lynn WA, Lightman S 2004. Syphilis and HIV: a dangerous combination. Lancet Infect Dis 4: 456-466.

Malkin K 1984. Enhancement of Leptospira hardjo agglutination titers in sheep and goat serum by heat inactivation. Can J Comp Med 48: 208-210.

O'Keefe JS 2002. A brief review on the laboratory diagnosis of leptospirosis. $N Z$ Vet $J$ 50: 9-13.

Plackett P, Alton GG 1975. A mechanism for prozone formation in the complement fixation test for bovine brucellosis. Aust Vet $J$ 51: $374-377$

Smith G, Holman RP 2004. The prozone phenomenon with syphilis and HIV-1 co-infection. South Med J 97: 379-382.

Tizard IR 2004. Veterinary immunology: an introduction, 7th ed., Saunders Company, Philadelphia, 494 pp.

Triola MF 2005. Introdução à estatística, 9th ed., Livros Técnicos Científicos Editora, Rio de Janeiro, 682 pp.

WHO - World Health Organization 2003. Human leptospirosis: guidance for diagnosis, surveillance and control, WHO Library Cataloguing-in-Publication Data, Geneva, 109 pp. 